\title{
Antimicrobial activity of a C-terminal peptide from human extracellular superoxide dismutase Mukesh Pasupuleti ${ }^{*}$, Mina Davoudi ${ }^{1}$, Martin Malmsten ${ }^{2}$ and Artur Schmidtchen ${ }^{1}$
}

Address: ${ }^{1}$ Division of Dermatology and Venereology, Department of Clinical Sciences, Biomedical Center B14, Lund University, Tornavägen 10 , SE-22184 Lund, Sweden and 2Department of Pharmacy, P.O. Box 580, Uppsala University, SE-75123 Uppsala, Sweden

Email: Mukesh Pasupuleti* - mukesh.pasupuleti@med.lu.se; Mina Davoudi - mina.davoudi@med.lu.se; Martin Malmsten - martin.malmsten@farmaci.uu.se; Artur Schmidtchen - artur.schmidtchen@med.lu.se

* Corresponding author

Published: 15 July 2009

BMC Research Notes 2009, 2:136 doi:10.1/86/1756-0500-2-136
Received: 12 january 2009

Accepted: 15 July 2009

This article is available from: http://www.biomedcentral.com/I756-0500/2//36

(C) 2009 Pasupuleti et al; licensee BioMed Central Ltd.

This is an Open Access article distributed under the terms of the Creative Commons Attribution License (http://creativecommons.org/licenses/by/2.0), which permits unrestricted use, distribution, and reproduction in any medium, provided the original work is properly cited.

\begin{abstract}
Background: Antimicrobial peptides (AMP) are important effectors of the innate immune system. Although there is increasing evidence that AMPs influence bacteria in a multitude of ways, bacterial wall rupture plays the pivotal role in the bactericidal action of AMPs. Structurally, AMPs share many similarities with endogenous heparin-binding peptides with respect to secondary structure, cationicity, and amphipathicity.

Findings: In this study, we show that RQA2I (RQAREHSERKKRRRESECKAA), a cationic and hydrophilic heparin-binding peptide corresponding to the C-terminal region of extracellular superoxide dismutase (SOD), exerts antimicrobial activity against Escherichia coli, Pseudomonas aeruginosa, Staphylococcus aureus, Bacillus subtilis and Candida albicans. The peptide was also found to induce membrane leakage of negatively charged liposomes. However, its antibacterial effects were abrogated in physiological salt conditions as well as in plasma.

Conclusion: The results provide further evidence that heparin-binding peptide regions are multifunctional, but also illustrate that cationicity alone is not sufficient for AMP function at physiological conditions. However, our observation, apart from providing a link between heparinbinding peptides and AMPs, raises the hypothesis that proteolytically generated C-terminal SODderived peptides could interact with, and possibly counteract bacteria. Further studies are therefore merited to study a possible role of SOD in host defence.
\end{abstract}

\section{Background}

Antimicrobial peptides (AMP) are short cationic peptides widely distributed at biological surfaces prone to infection, playing important roles in innate immunity [1]. At present at least 900 different AMP have been discovered http://www.bbcm.univ.trieste.it/ tossi/search.htm. Many AMPs are characterized by an amphipathic structure, where clusters of hydrophobic and cationic amino acids are spatially organized in sectors within the molecules. For example, AMPs comprise linear peptides, many of which may adopt $\alpha$-helical and amphipathic conformation upon bacterial binding, peptides forming cysteinelinked antiparallel $\beta$-sheets, as well as cysteine-constrained loop structures. AMPs may also, however, be 
found among peptides not displaying such ordered structures as long as these are characterized by an over-representation of certain amino acids [1]. Considering the role of peptide secondary structure and amphphilicity, as well as the composition of bacterial membranes, AMP function has been thought to involve direct binding to the lipid bilayer, and the interaction with bacterial membranes is a prerequisite for AMP function. However, the modes of action of AMPs on their target bacteria are complex, and can be divided into membrane disruptive and non-membrane disruptive $[1,2]$. Nevertheless, the lack of a specific molecular microbial target minimizes the risk of resistance development and thus AMPs may have therapeutic potential [3].

Superoxide dismutase (SOD) is a metalloenzyme that catalyzes the dismutation of superoxide radicals [4]. Mammalian cell produce two different types of SOD, one intracellular and one extracellular form. Extracellular superoxide dismutase (EC-SOD) is the major form $(>90 \%$ of total), present in all extracellular fluids, including plasma, lymph, synovial fluid, brain grey matter, liver, kidney, and spleen $[4,5]$. Interestingly EC-SOD, via its Cterminal domain, binds to glycosaminoglycans, such as heparan sulfate and heparin [6-9]. We have previously shown that cationic AMPs, including cathelicidins and defensins, may interact with negatively charged glycosaminoglycans (GAGs) like heparin [10]. Conversely, we have demonstrated that heparin-binding motifs $[11,12]$, as well as peptide sequences of endogenous proteins including peptides derived from complement $[13,14]$, human kininogen [15], matrix proteins [16], growth factors [17], and histidine-rich glycoprotein $[18,19]$, all exhibit antimicrobial effects, thus acting as "classical" peptides and proteins of innate immunity. These observations prompted us investigate possible antimicrobial effects of the C-terminal heparin binding domain of EC-SOD. We here identify such an activity, and define it in terms of action on various microbes and on eukaryotic cells, as well as the influence on these effects of plasma and the ionic environment.

\section{Materials \\ Peptides and bacteria}

The peptides RQA21 (RQAREHSERKKRRRESECKAA) and LL-37 (LLGDFFRKSEKIGKEFKRIVQRIKDFLRN-

LVPRTES) were from Innovagen $\mathrm{AB}$, Lund, Sweden. The purity (>95\%) and molecular weight of these peptides was confirmed by mass spectral analysis (MALDI.TOF Voyager). Escherichia coli ATCC 25922 and clinical isolate 37.4, Pseudomonas aeruginosa ATCC 27853 and clinical isolate 27.5, Staphylococcus aureus ATCC 29213 and clinical isolate 4, Bacillus subtilis ATCC 6633, and Candida albicans ATCC 90028 were all obtained from the Department of Clinical Bacteriology at Lund University Hospital.

\section{Radial diffusion assay}

This was performed according to procedures described previously [20]. $6 \mu \mathrm{l}$ of test sample $(100 \mu \mathrm{M})$ was added to each well and for comparison, LL-37 was used.

\section{Viable-count analysis}

E. coli 37.4 were subjected to peptides at 30 and $60 \mu \mathrm{M}$ in $10 \mathrm{mM}$ Tris, with or without $0.15 \mathrm{M} \mathrm{NaCl}$ as previously described [20].

\section{Hemolysis and LDH assay}

These assays were preformed according to procedures described previously $[17,20]$.

\section{Liposome preparation and leakage assay}

The liposomes investigated were anionic (DOPE/DOPG $75 / 25 \mathrm{~mol} / \mathrm{mol})$. DOPG (1,2-Dioleoyl-sn-Glycero-3Phosphoglycerol, monosodium salt) and DOPE (1,2-dioleoyl-sn-Glycero-3-phoshoethanolamine) were from Avanti Polar Lipids (Alabaster, USA) and of $>99 \%$ purity. Leakage assay was performed according to previously published procedures [20]. A SPEX-fluorolog 1650 0.22$\mathrm{m}$ double spectrometer (SPEX Industries, Edison, USA) was used for the liposome leakage assay. Measurements were performed in triplicate at $37^{\circ} \mathrm{C}$.

\section{Results}

To investigate whether RQA21 posses antimicrobial activity, we tested the peptide against a microbe panel consisting of Gram-positive and Gram-negative bacteria, as well as yeast. The results showed that the peptides were antibacterial in radial diffusion assays (RDA) against the Gram-negative Escherichia coli and Pseudomonas aeruginosa, the Gram-positive Bacillus subtilis and Staphylococcus aureus, as well as the fungal isolate Candida albicans (Figure $1 \mathrm{~A}$ ). Although variability in the different sensitivities was noted, the zone of inhibition results were lower than those observed for the benchmark antimicrobial peptide LL-37. Interestingly, it was observed that the two clinical Gram-negative isolates (E. coli and P. aeruginosa) were particularly sensitive to RQA21.

It is well-known that activities of AMPs are dependent of the microenvironment. For example, various chemokines, defensins, as well as LL-37, are partly or completely, antagonized by high salt conditions or the presence of plasma proteins in vitro $[21,22]$. We therefore examined the influence of physiological salt $(0.15 \mathrm{M} \mathrm{NaCl})$ on the antimicrobial activity of RQA21 against E. coli 37.4 using viable count analysis. As shown in Figure 1B, RQA21 efficiently killed E. coli, at both 30 and $60 \mu \mathrm{M}$ in $10 \mathrm{mM}$ Tris buffer. However, at physiological salt conditions the peptide exerted no detectable antimicrobial activity (Figure 1B). This contrasted to LL-37, which was active under both conditions. In order to explore the effect of plasma 
A
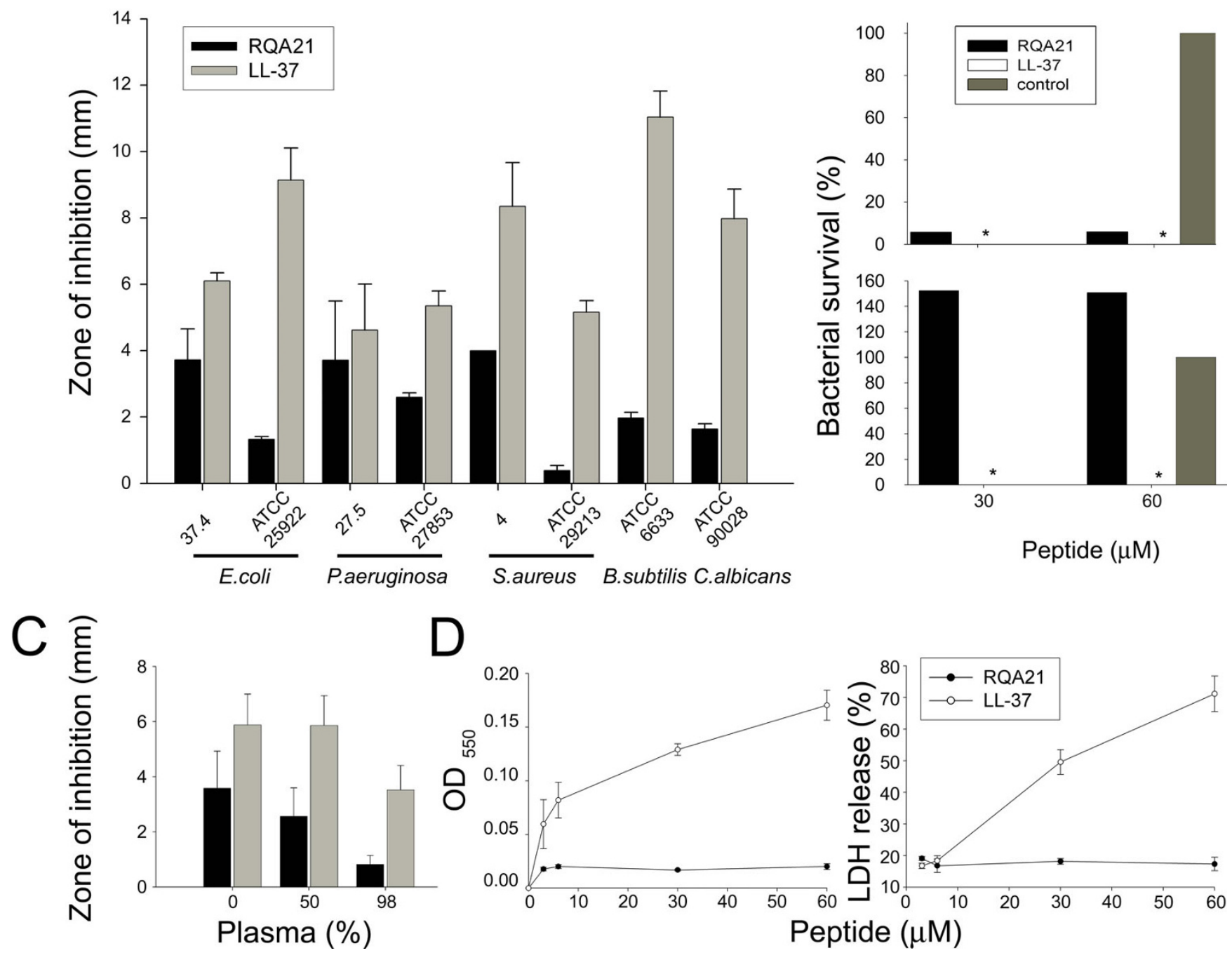

Figure I

Activities of selected peptides. (A) Antimicrobial activity of RQA2 I and LL37 peptides (at I00 $\mu$ M in RDA) against the indicated microbes. Bacteria $\left(4 \times 10^{6} \mathrm{cfu}\right)$ or C. albicans ATCC $90028\left(\mathrm{I} \times 10^{5}\right)$ was inoculated in $0.1 \%$ TSB agarose gel. The zones of clearance correspond to the inhibitory effect of each peptide $(6 \mu \mathrm{l}$ at $100 \mu \mathrm{M})$ after incubation at $37^{\circ} \mathrm{C}$ for $18-24 \mathrm{~h}$ (mean values are presented, $\mathrm{n}=3$ ). (B) $2 \times 10^{6}$ colony-forming units $/ \mathrm{ml}$ of $E$. coli 37.4 bacteria were incubated in $50 \mu l$ with peptides at 30 and $60 \mu \mathrm{M}$ for 2 hours followed by plating on TSB agar plates and cfu were determined. Upper panel; in $10 \mathrm{mM}$ Tris, $\mathrm{pH} 7.4,5 \mathrm{mM}$ glucose, lower panel; the same buffer with $0.15 \mathrm{M} \mathrm{NaCl}$. (C) Antimicrobial activity of RQA2I and LL37 peptides (at $100 \mu \mathrm{M}$ in RDA) against $E$. coli 37.4 in the presence of citrate plasma at the indicated concentrations. (D) Left panel; Analysis of hemolytic effects of RQA2I peptide and comparison with LL-37. The cells were incubated with peptides at the indicated concentrations ( $\mathrm{x}$-axis). 2\% Triton X-I00 (Sigma-Aldrich) served as positive control. The absorbance of hemoglobin release was measured at $\lambda 550 \mathrm{~nm}$ and is expressed as \% of Triton $X-100$ induced hemolysis $(y$-axis) ( $n=3$, mean values and SD is indicated). Right panel; $\mathrm{HaCaT}$ keratinocytes were subjected to RQA2I and LL-37. Cell permeabilizing effects were measured by the LDH based TOX-7 kit.

on the activity of RQA21, different concentrations of citrate plasma $(0,50,98 \%)$ was added to the peptides and activity assayed using RDA (Figure 1C). The activity decreased proportionately with an increase in the plasma concentration, similar effects being observed for the benchmark LL-37.
To shed some further light on RQA21, toxicity studies against human erythrocytes and keratinocytes were performed, with no hemolytic activity detected at doses of 3$60 \mu \mathrm{M}$ (Figure 1D, left panel). This contrasted to the antimicrobial peptide LL-37, which permeabilised erythrocytes at doses $>6 \mu \mathrm{M}$. Analogously, RQA21 did not 
permeabilise human epithelial cells (HaCaT keratinocyte cell line), whereas LL-37 exerted permeabilising activity at doses of 30-60 $\mu \mathrm{M}$ (Figure 1D, right panel). Additionally, RQA21 and LL-37 both permeabilised model lipid membranes at $1 \mu \mathrm{M}$. In parallel to the bactericidal results, LL37 was the more potent of the two peptides in respect to liposome permeabilisation (Figure 2). Kinetic analysis showed that $\sim 80 \%$ of the maximal release caused by each peptide occurred within 5-10 minutes for both LL-37 and RQA21 (Figure 2).

\section{Discussion}

The findings in this report, showing that a peptide segment of EC-SOD exerts antimicrobial activities, further underscore that endogenous proteins may harbour cryptic, antimicrobial epitopes. Table 1 exemplifies the diversity of such "non-classical" antimicrobial peptides, originating from diverse proteins and that originate from sequences known to interact with glycosaminoglycans. In the light of this, our findings indicate that a strategy based on selection of peptides of heparin-binding human proteins may prove to be fruitful in the discovery of additional novel sequences as lead candidates for the development of AMPs based on endogenous peptides.

RQA21 ( $\mathrm{NH}_{2}$-RQAREHSERKKRRRESECKAA-COOH), is rich in basic amino acids, with a net charge of +6 at $\mathrm{pH}$ 7.4 , and is also strongly hydrophilic having a low relative hydrophobic moment $(0.24$, Kyte \& Doolittle scale, see http://www.bbcm.univ.trieste.it/ ntossi/HydroCalc/

HydroMCalc.html. Previous investigations of the structure of the C-terminal part of SOD indicate that the peptide region may assume helical structures, and that arginine side chains take part in the binding to heparin. However, the analysis also suggested that this peptide

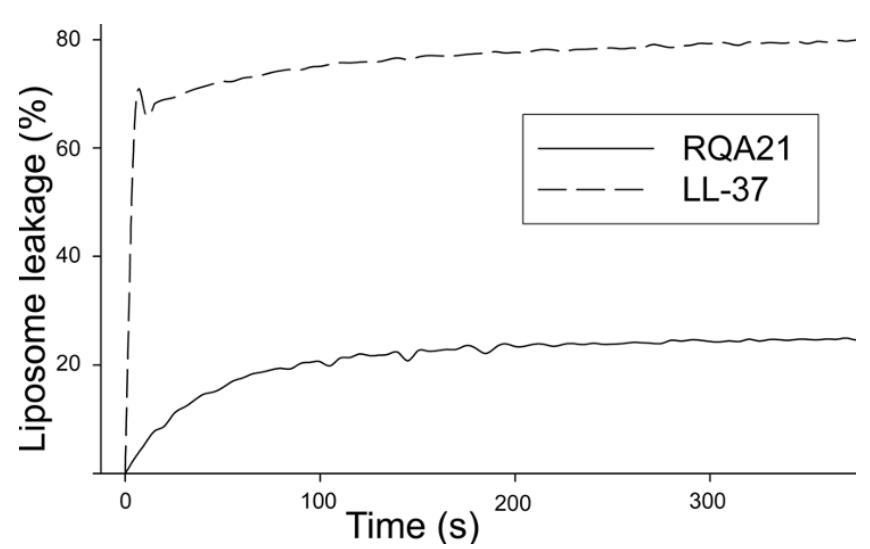

Figure 2

Effects of RQA2I and LL-37 on liposome leakage

kinetics. The membrane permeabilizing effect of the indicated peptides (at I $\mu M$ ) was recorded by measuring fluorescence release of carboxyfluorescein from liposomes. region exist in an equilibrium between different conformations, where helical as well as random structures are likely to be present [6]. Thus, considering the low hydrophobicity of RQA21, the peptide likely resembles other linear peptides having a low helical content. For example, AMPs derived from growth factors display a low helical content in buffer and in presence of membranes, reflecting their low content of features typical of "classical" helical peptides, such as regularly interspersed hydrophobic residues [17]. Furthermore, studies utilizing ellipsometry, $\mathrm{CD}$, fluorescence spectroscopy, and z-potential measurements on a kininogen-derived antimicrobial peptide, HKH20 (HKHGHGHGKHKNKGKKNGKH) [23] showed that the HKH20 peptide display primarily random coil conformation in buffer and at lipid bilayers, the interactions dominated by electrostatics, as evidenced by strongly reduced adsorption and membrane rupture at high ionic strength [23]. Interestingly, both HKH20 [15] and GKR22 (GKRKKKGKGLGKKRDPCLRKYK) [17], a peptide derived from heparin-binding growth factor, retain antibacterial activity in physiological buffers as well as in plasma. In contrast to these observations, RQA21 lost its antibacterial activity at high salt concentrations, illustrating the well-known fact that cationicity alone is not a sufficient parameter for determining antimicrobial activity of a given peptide, and exemplifying that amphipathicity, as well as hydrophobicity, enabling bacterial membrane interactions, are necessary for activity of many AMPs [1], especially at physiological salt concentrations, where initial electrostatic interactions with anionic cell wall components are diminished by the ionic environment. Clearly, AMPs and other antimicrobial proteins are dependent of the microenvironment, and may be also antagonized the presence of plasma proteins in vitro $[17,19,21,22]$. Nevertheless, there is now convincing evidence that AMPs contribute to enhanced bacterial killing in vivo, likely reflecting the necessity of AMP compartmentalization (diminishing toxic effects on nearby eukaryotic cells), presence of ionic microenvironments, or synergism between AMPs, as well as their additional roles as immune modifiers [24].

Bacterial surfaces contain many anionic components, including LPS and anionic lipids of Gram-negative bacteria, as well as teichoic and teichuronic acids of Gram-positive bacteria. Beyond the outer cell surface, AMPs interact with the plasma membrane. Contrasting to eukaryotic membranes, which contain mostly zwitterionic lipids (e.g., phosphatidylcholine), and sterols, bacterial membranes comprise various acidic phospholipids (phosphatidylglycerol, phosphatidylserine and cardiolipin), which confer a negative charge facilitating AMP binding and sometimes also defect formation $[25,26]$. Furthermore, it has also become increasingly clear that AMP selectivity may also depend on factors such as AMP oli- 
Table I: Examples of "non-classical" antimicrobial peptides, originating from diverse heparin-binding (poly)peptides.

\begin{tabular}{|c|c|c|}
\hline Origin & Sequence & Reference \\
\hline \multicolumn{3}{|l|}{ Plasma proteins } \\
\hline Complement factor $\mathrm{C} 3$ & LGEACKKVFLDCCNYITELRRQHARAS & {$[13,14]$} \\
\hline High molecular weight kininogen & HKHGHGHGKHKNKGKKNGKH & {$[15]$} \\
\hline Fibronectin & QPPRARITGYIIKYEKPG & {$[17]$} \\
\hline Protein $C$ Inhibitor & SEKTLRKWLKMFKKRQLELY & {$[11]$} \\
\hline Histidine-rich glycoprotein & GHHPHGHHPHGHHPHGHHPH & {$[18,19]$} \\
\hline \multicolumn{3}{|l|}{ Extracellular proteins } \\
\hline Amphiregulin & LKKNGSCKRGPRTHYGQKAIL & [17] \\
\hline Heparin-binding EGF-like growth factor & GKRKKKGKGLGKKRDPCLRKYK & [17] \\
\hline \multicolumn{3}{|l|}{ Fibroblast growth factor } \\
\hline Hepatocyte growth factor & LKIKTKKVNTADQCANRCTRNKGL & \\
\hline Vitronectin & AKKQRFRHRNRKGYR & {$[\mathrm{II}]$} \\
\hline PRELP & QPTRRPRPGTGPGRRPRPRPRP & [17] \\
\hline \multirow[t]{3}{*}{ Laminin chains } & SRNLSEIKLLISQARK & {$[11]$} \\
\hline & KDFLSIELFRGRVKV & \\
\hline & LGTRLRAQSRQRSRPGRWHKVSVRW RLRAQSRQRSRPGRWHKVSVRW & \\
\hline
\end{tabular}

gomerisation and preassembly (in solution and membrane) [27]. Clearly, all these factors determine the ultimate activity of a given AMP under specific conditions. Although high AMP activity can sometimes be reached by highly charged and hydrophilic AMPs [15,17], Gram-positive pathogens such as Staphylococcus aureus have a relatively low electrostatic surface potential, which may be reduced or even reversed, e.g., by L-lysine modification of phosphatidylglycerol, and D-alanine modification of cell wall teichoic acid, reducing AMP binding to Gram-positive bacteria, respectively [28]. Likely, these mechanisms, together with the high electronegativity of LPS, explain the herein noted higher sensitivity of the two clinical Gram-negative isolates (E. coli and $P$. aeruginosa) to the cationic RQA21.

It is well established that SOD serves a key antioxidant role. Mice lacking SOD2 die within days after birth due to massive oxidative stress [29]. In contrast, mice lacking SOD3 (EC-SOD) have a reduced life-span, although not otherwise showing any obvious defects during devlopment and early adulthood [30]. Currently, no data are available on the immune status and infection sensitivity of these mice. Clearly, and as mentioned above, caution should be executed when assigning possible functional roles for peptides based on their in vitro activities only. However, our observation, apart from providing a link between heparin-binding peptides and AMP activity in vitro, raises the hypothesis that proteolytically generated C-terminal SOD-derived peptides could interact with, and possibly counteract bacteria in vivo. Further studies are merited in order to investigate proteolysis of SOD, possi- ble release of C-terminal peptides, and their potential bioactive roles under physiological conditions.

\section{Competing interests}

Martin Malmsten and Artur Schmidtchen are co-founders, and members of the board of DermaGen $\mathrm{AB}$, which develops antimicrobial peptide therapeutics for commercial purposes.

\section{Authors' contributions}

AS and MM conceived the study together, while MP, AS, and MM planned the study and jointly wrote the paper together. MP performed experiments on bacteria. MD performed the eukaryotic assays experiments. MM performed experiments on liposome leakage. All the authors have read and approved the final manuscript.

\section{Acknowledgements}

This work was supported by grants from the Swedish Research Council (projects I347I and 62 I-2003-4022), the Royal Physiographic Society in Lund, the Welander-Finsen, Söderberg, Schyberg, Crafoord, Alfred Österlund, and Kock Foundations, DermaGen AB, and The Swedish Government Funds for Clinical Research (ALF).

\section{References}

I. Yount NY, Bayer AS, Xiong YQ, Yeaman MR: Advances in antimicrobial peptide immunobiology. Biopolymers 2006, 84:435-458.

2. Brogden KA: Antimicrobial peptides: pore formers or metabolic inhibitors in bacteria? Nat Rev Microbiol 2005, 3:238-250.

3. Marshall SH: Antimicrobial peptides: A natural alternative to chemical antibiotics and a potential for applied biotechnology. Electronic Journal of Biotechnology 2003, 6:3 [http://www.ejbio technology.info/content/vol6/issue3/full/I/BIP/index.html].

4. Marklund SL: Expression of extracellular superoxide dismutase by human cell lines. Biochem J 1990, 266:213-219. 
5. Marklund SL: Extracellular superoxide dismutase in human tissues and human cell lines. J Clin Invest 1984, 74: I398-I 403.

6. Tibell LA, Sethson I, Buevich AV: Characterization of the heparin-binding domain of human extracellular superoxide dismutase. Biochim Biophys Acta 1997, 1340:2 I-32.

7. Inoue M, Watanabe N, Morino Y, Tanaka Y, Amachi T, Sasaki J: Inhibition of oxygen toxicity by targeting superoxide dismutase to endothelial cell surface. FEBS Lett 1990, 269:89-92.

8. Sandstrom J, Carlsson L, Marklund SL, Edlund T: The heparin-binding domain of extracellular superoxide dismutase $\mathbf{C}$ and formation of variants with reduced heparin affinity. J Biol Chem 1992, 267: 18205-18209.

9. Lookene A, Stenlund P, Tibell LA: Characterization of heparin binding of human extracellular superoxide dismutase. Biochemistry 2000, 39:230-236.

10. Schmidtchen A, Frick IM, Björck L: Dermatan sulphate is released by proteinases of common pathogenic bacteria and inactivates antibacterial alpha-defensin. Mol Microbiol 2001, 39:708-7।3.

1I. Andersson E, Rydengård V, Sonesson A, Mörgelin M, Björck L Schmidtchen A: Antimicrobial activities of heparin-binding peptides. Eur J Biochem 2004, 27 I: 12 1 9-1226.

12. Kacprzyk L Rydengard V, Morgelin M, Davoudi M, Pasupuleti M, Malmsten M, Schmidtchen A: Antimicrobial activity of histidinerich peptides is dependent on acidic conditions. Biochim Biophys Acta 2007, I 768:2667-2680.

13. Nordahl EA, Rydengård V, Nyberg P, Nitsche DP, Mörgelin M, Malm-

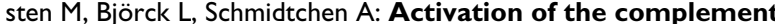
system generates antibacterial peptides. Proc Natl Acad Sci USA 2004, 101:16879-16884

14. Pasupuleti M, Walse B, Nordahl EA, Morgelin M, Malmsten M, Schmidtchen A: Preservation of antimicrobial properties of complement peptide $\mathrm{C} 3 \mathrm{a}$, from invertebrates to humans. J Biol Chem 2007, 282:2520-2528.

15. Nordahl EA, Rydengård V, Mörgelin M, Schmidtchen A: Domain 5 of high molecular weight kininogen is antibacterial. I Biol Chem 2005, 280:34832-34839.

16. Malmsten M, Davoudi M, Schmidtchen A: Bacterial killing by heparin-binding peptides from PRELP and thrombospondin. Matrix Biol 2006, 25:294-300.

17. Malmsten M, Davoudi M, Walse B, Rydengard V, Pasupuleti M, Morgelin $M$, Schmidtchen $A$ : Antimicrobial peptides derived from growth factors. Growth Factors 2007, 25:60-70.

18. Rydengard V, Olsson AK, Morgelin M, Schmidtchen A: Histidinerich glycoprotein exerts antibacterial activity. Febs J 2007, 274:377-389.

19. Rydengard V, Shannon O, Lundqvist K, Kacprzyk L, Chalupka A, Olsson AK, Morgelin M, Jahnen-Dechent W, Malmsten M, Schmidtchen A: Histidine-rich glycoprotein protects from systemic Candida infection. PLoS Pathog 2008, 4: I 000116.

20. Pasupuleti M, Walse B, Svensson B, Malmsten M, Schmidtchen A Rational design of antimicrobial C3a analogues with enhanced effects against Staphylococci using an integrated structure and function-based approach. Biochemistry 2008, 47:9057-9070.

21. Ganz T: Antimicrobial proteins and peptides in host defense. Semin Respir Infect 200I, 16:4-10.

22. Wang Y, Agerberth B, Lothgren A, Almstedt A, Johansson J: Apolipoprotein $A-I$ binds and inhibits the human antibacterial/ cytotoxic peptide LL-37. J Biol Chem 1998, 273:33II5-33II8.

23. Ringstad L, Kacprzyk L, Schmidtchen A, Malmsten M: Effects of topology, length, and charge on the activity of a kininogenderived peptide on lipid membranes and bacteria. Biochim Biophys Acta 2007, I768:715-727.

24. Bowdish DM, Davidson DJ, Lau YE, Lee K, Scott MG, Hancock RE: Impact of LL-37 on anti-infective immunity. J Leukoc Biol 2005, 77:45I-459.

25. Durr UH, Sudheendra US, Ramamoorthy A: LL-37, the only human member of the cathelicidin family of antimicrobial peptides. Biochim Biophys Acta 2006, I758:| |408-| 425.

26. Henzler-Wildman KA, Martinez GV, Brown MF, Ramamoorthy A: Perturbation of the hydrophobic core of lipid bilayers by the human antimicrobial peptide LL-37. Biochemistry 2004, 43:8459-8469.
27. Sal-Man N, Oren Z, Shai Y: Preassembly of membrane-active peptides is an important factor in their selectivity toward target cells. Biochemistry 2002, 41: I I 921 - I 1930.

28. Nizet V: Antimicrobial peptide resistance mechanisms of human bacterial pathogens. Curr Issues Mol Biol 2006, 8: I I-26.

29. Li Y, Huang TT, Carlson E], Melov S, Ursell PC, Olson JL, Noble LI, Yoshimura MP, Berger C, Chan PH, Wallace DC, Epstein C): Dilated cardiomyopathy and neonatal lethality in mutant mice lacking manganese superoxide dismutase. Nat Genet 1995, I I:376-381.

30. Elchuri S, Oberley TD, Qi W, Eisenstein RS, Jackson Roberts L, Van Remmen H, Epstein CJ, Huang TT: CuZnSOD deficiency leads to persistent and widespread oxidative damage and hepatocarcinogenesis later in life. Oncogene 2005, 24:367-380.

Publish with Biomed Central and every scientist can read your work free of charge

"BioMed Central will be the most significant development for disseminating the results of biomedical research in our lifetime. "

Sir Paul Nurse, Cancer Research UK

Your research papers will be:

- available free of charge to the entire biomedical community

- peer reviewed and published immediately upon acceptance

- cited in PubMed and archived on PubMed Central

- yours - you keep the copyright 